\title{
HEALTH POLICY PROBLEMS IN INDONESIA'S BORDER REGION
}

\author{
Posma Sariguna Johnson Kennedy ${ }^{\varpi}$ \\ Duta Wacana Christian University, Indonesia
}

\begin{abstract}
This paper aims to study health policy problems in Indonesia's border areas. It is especially focused on the case of health problems in Nusa Tenggara Timur Province. The research method used is a quantitative description approach. It is necessary to increase the development of health infrastructure and its supporters in border areas. It is also necessary to socialise and improve health insurance services from the government, as well as improve human resources in the health sector.
\end{abstract}

Key words: health policy, health problems, border area, Nusa Tenggara Timur JEL codes: I18, O11

\section{INTRODUCTION}

Health development is currently facing inequity and disparity, especially health services between regions and income groups in Indonesia. Access to primary health services is still limited, especially in the disadvantaged, border, and island areas. Geographical constraints cause limited access to health services in many areas. Quality of service is not optimal because many necessary health facilities do not meet service readiness standards and lack health service standards.

Essential health services are needed in order to achieve the Sustainable Development Goals (SDGs) 2030 targets. The success of critical health services by prioritising promotive and preventive services will reduce the burden of further assistance. Essential health services consist of several types of health services that are considered necessary for maintaining the health of a person, family, and community to live productively socially and economically.

In Indonesia, two provisions specify the types of essential services: the Minister of Health Regulation
43/2016 concerning Minimum Service Standards and the Minister of Health Regulation 75/2014 on Community Health Centres. Essential health services require promotive, preventive, screening, curative, and rehabilitative services. They must be provided comprehensively and holistically to both community groups and individuals, and cannot be partial.

Public issues arise in border areas because they are remote, often in the form of islands, and have extreme topography. Therefore, the role of infrastructure is also a significant physical component for the border regions. Systematic, consistent, and targeted infrastructure development will lead to an increase in the welfare of border communities. The primary health issue is the availability of health support services and facilities, which are still low because the distribution is uneven, only concentrated in big cities [Suharmiati et al. 2013].

This study aims to assess the problems of health policy in the border area. Specifically, as an example case, the health and nutrition problems in Nusa Tenggara Timur Province. The research method uses 
a quantitative description approach. The researcher uses various literature reviews and several data sources as secondary data.

\section{BASIC HEALTH SERVICES}

The spatial inequality of the social development process in marginalised areas is mostly rural. Peripherals are complex and multidimensional concepts with properties such as backwardness, dependence, marginalisation, and appropriation. Weak regions and boundaries, whose relations and interconnections lead to permanent exclusion and marginalisation, find it difficult to break away from "dependence", without outside interference. On the other hand, it must be explained that spatial inequality is a feature of socio-economic development and is an inevitable phenomenon [Magnusson and Ottosson 2009]. High costs are a barrier to the transfer of quality human resources to the suburbs. In financial investment and worker training, prices are not enough to absorb innovation to improve the economy and society in border areas, including in essential health services [Klimczuk and Klimczuk-Kochańska 2015].

Basic health services are first-level health services and are the first contact of the population with the health service system, including promotive and preventive activities, health assessments, diagnosis and treatment for acute and chronic conditions, and rehabilitation services (Ontario Health Services Restructuring Commission, Primary Health Care Strategy). Basic health services are defined as a set of first-level services that are universally accessible that promote health, prevent disease, and provide diagnostic, curative, rehabilitative, supportive, and palliative services. Basic health services refer to approaches to the spectrum of services outside the traditional health service system, covering all functions that play a role in health, income, housing, education, and the environment [Muldoon et al. 2006].

Some countries recognise the vital role of essential health services to improve public health status and have made efforts to reform critical health services. In Turkey, health reform began in 2003 and brought significant changes in primary health care [Cevik et al. 2017]. The China National Roadmap 2030 emphasised the vital role of primary health services, which must be supported by political commitments to strengthen the central health care system [Li et al. 2017]. Essential health services are an effective way to: (1) reduce social disparities and exclusions in health matters; (2) improve equity; (3) meet the needs and expectations of the people; (4) minimise poverty; (5) integrate health with other sectors; (6) encourage leadership that promotes cooperation and dialogue; (7) increase the effectiveness of the health budget; (8) increase accountability of health service facilities; and (9) increase the responsibility of state administrators [WHO 2012].

To overcome the unequal health status and access to health services in the world, the World Health Organization (WHO) in the Alma Ata Declaration of 1978 recommended two strategies, namely: (1) to approach Primary Health Care; and (2) to formulate a National Health System. In the declaration, Primary Health Care is translated as several "essential health services that are scientifically accountable, socially acceptable, accessible to every individual/family, organised with the participation of the community, economically can be borne by the town and country, accompanied by a spirit of independence (self-reliance and self-determination)". Primary Health Care is the first level of the individual, family, and community contact with the national health system to bring health services as close as possible to the residence and workplace.

In the Alma Ata Declaration [WHO 1978] there are five basic principles for the fulfilment of primary health services, including: (1) equitable distribution of health efforts; (2) emphasis on preventive efforts; (3) the use of appropriate technology in health efforts; (4) community participation in the spirit of independence, and (5) cross-sectoral cooperation in developing health. In addition, the four pillars of basic health service reform that have been initiated by the WHO [2008] consist of:

- Health financing reform. Government funding is directed more at public health efforts and health services for the poor.

- Health policy reform. Health policy must be evidence-based.

- Health leadership reform. Health leadership must be inclusive, participatory, and able to move across sectors through advocacy competencies. 
- Health service reform. Basic health services must develop a robust system in the context of the Community Health Centres with its network and with its supra system (district/city health office, and district/city hospital).

\section{BORDER HEALTH ISSUES}

The border area should be the State Storefront or the forefront of the territory of the Republic of Indonesia, which should look good because it is located on the front. But so far, there has been a disparity in the border regions with neighbouring countries. They still have difficulty accessing basic needs, such as education, health, nutritional adequacy, and employment. Their condition is deplorable, not so with neighbouring countries. Therefore, the border area must become a standard interface space where the border community's cosmopolitanism is seen as the power to build a prosperous Homeland front page [Kennedy 2018].

Remote areas, borders and islands, have extreme topography. Besides, geographical conditions are still isolated due to limited road infrastructure, land transportation, rivers, and other public facilities. This condition impacts the health of social welfare, economy, education, and skills of border communities that are still lagging. Therefore the border area must be a top priority for infrastructure development. There is a significant correlation between the condition of infrastructure with the pulse of community socio-economic activities and the welfare of the people on the border. Infrastructure development will lead to an increase in the health of border communities [Shanteukie WordPress 2011].

The availability of health services and supporting facilities in the disadvantaged areas, the border, and islands is still low. The available resources and the number of health workers needed in the field of promotive, preventive, curative, and rehabilitative efforts are always mostly concentrated in big cities. Even though the number of health workers is sufficient, their distribution is not evenly distributed. Optimisation of health workers is one effort to improve the availability, equity, and quality of health workers, especially in remote, disadvantaged, border, and island areas. Local health workers' distribution must be optimised, especially in remote areas [Suharmiati 2013].

Primary health services in Indonesia's border regions are still low. Community Health Centre (Puskesmas), the primary function of the mainstay of service for the community, has not been able to provide maximum facilities for remote areas, especially in border areas. Due to the large working area of the Puskesmas, geographically, it is partly challenging to reach, the population is small, scattered in small groups that are far apart. Means of transportation are also minimal with expensive costs, land, river, sea, and air. One reason is because of severe geographical conditions and climate/weather that often changes. The status of public health and coverage of health services in remote border areas is still low. Society, in general, does not yet have the knowledge and behaviour of healthy living and unfavourable environmental conditions. Puskesmas services in remote border areas are affected, among other issues, by the affordability of services.

Access to health services is not only caused by distance problems, but there are two determinants, namely, the supply and demand factors. Determinants of supply consist of service organisations and physical infrastructure, place of service, availability, utilisation, distribution of officers, service costs, and service quality. The determinants of demand, which are user factors, include the low education and socio-cultural conditions of the community and the weak or inadequate level of community income. The primary need for sufficient access to services is the availability of facilities and staff, distance, and financially affordable and socio-cultural issues that users can accept [Timyan 1997].

The availability of frequently changing assignment doctors in border areas also affects the management of the Puskesmas. Doctors with a contract period of one year, were too short to manage the Puskesmas properly because, within that period, they had not mastered the Puskesmas program yet. Besides, doctors need to adapt to the environment, and it takes time for people to get to know them. Health centre resources, especially in remote border areas, still need to be improved, especially regarding the balance of work tenure, workload, and rewards for health workers. 
The low number of patients visiting the Puskesmas shows that the main Puskesmas is challenging to reach by the community, due to geographical location, lack of transportation facilities, and the low ability to pay for transportation costs. The district expects those Puskesmas health workers to provide medical services at home or in places close to where they live. Therefore, the community tends to call health workers at home, considering the same costs if they have to go to the Puskesmas and is facilitated with a cell phone. This situation shows the high ineffectiveness of time spent by nurses and midwives in carrying out their duties at the health centre [Budiarto et al. 2007].

The number of health workers available at the Puskesmas have not been able to complete all mandatory health efforts carried out at the Puskesmas, especially services outside the building. This is due to the area of the Puskesmas and the difficulty in reaching the target. Therefore, the number of health service activities was reduced by the number of visits. As a result, the coverage of services outside the building was lower.

Meeting the health workers' needs in the Puskesmas in remote and border areas needs to consider the situation and condition of the local Puskesmas. In some Puskesmas, some officers were incompetent with their responsibilities. For example, drug services, health promotion, and eradication of infectious diseases was carried out by workers who only graduated from junior high or high school. Planning for staff needs at the Puskesmas should be carried out with a macro-level analysis of the long-term effects of various training strategies and employee recruitment. Furthermore, microanalysis of the profile of health workforce activities was also carried out. The macro analysis will determine the number of personnel to plan, while microanalysis will determine the type of health workers who should be recruited. The deployment of personnel began with assessing local service needs after going through functional analysis [Budiarto et al. 2005].

Drug acquisition is generally not under the request. Many health worker complaints about the discrepancy between the type and amount of drugs with cases of the disease being treated are things that need attention. In fulfilling drug needs, it should be adjusted to the epidemiology in the Puskesmas area. The epidemiology of condition is essential in setting priorities and target populations. By studying the spread of disease in the Puskesmas area, it can be used to determine the focal point of service related to the type and amount of drugs and the types of health equipment [Baker and Reinke 1994].

Health equipment and health support facilities (laboratories) in the Puskesmas are inadequate. Lack of health equipment and health support facilities (laboratories) in Puskesmas often disappoints people who have to travel long and arduous trips. This situation further strengthened the interest of the community not to go to the Puskesmas. The availability of medical devices, consumables, and medicine needs to be increased according to the needs of each Puskesmas. Communication and transportation tools must be met to make public health centres affordable to the community. Therefore it is necessary to offer medical devices and consumables that support health services, especially for cases of the disease that often occurs in health centres. Many emergency cases require special equipment and skills, but in reality, they are still lacking. Since the Puskesmas and its network are the first targets for handling emergency cases, the provision of emergency equipment needs to be available in all Puskesmas systems. It is necessary to provide skills to the health workers [Ristrini et al. 2004, Handayani et al. 2006].

\section{CASE OF NUSA TENGGARA TIMUR PROVINCE}

The Province of Nusa Tenggara Timur (referred to as NTT) is of interest. This region consists of 21 regencies/cities, with a population of 4,256,200 inhabitants. The number of poor people is around $66.54 \%$ of the total population in NTT Province. It is one of the areas that is not getting much attention. The more east, the more uneven development is so that development inequality is felt to impact social disparities. Poverty is assessed by several factors, namely: (1) education; (2) human resources; (3) income per capita and (4) access to health services [Triwahyuni 2010]. In fulfilling the basic rights of the community, one of the most important is access to health services. The limited access and the low quality of health 
services will have implications for: (1) low endurance to work for a living; (2) limited ability of children from families to grow and develop, and (3) low levels of maternal health ${ }^{1}$.

The HDI value for NTT Province ranks third lowest nationally after Papua and West Papua. The NTT HDI growth is lower than the national rate in 2017 , which amounted to $0.91 \%$ [RPJMN NTT 2018]. The HDI of NTT Province for the period 2013-2017 experienced an average increase of $1.86 \%$. The NTT HDI continues to increase, namely from 2016 it amounted from 67.75 to 68.28 in 2017 or increased by 0.36 in three years. Based on the national average from 2005 to 2012 , NTT is in the 31 st position of 34 provinces. Although NTT HDI continues to increase nationally, it is still far behind. In 2012, HDI of NTT Province is 60.81 , which lagged far back from the national (Indonesia) average HDI, which reached 67.70. Then it continued to lag until 2017 when the HDT NTT was 63.73 , and the national average HDI had reached 70.81 [RPJMN NTT 2018].

Low HDI is mainly due to the per capita expenditure indicator, which is only 7.12 million and is the lowest per capita expenditure in Indonesia. The average ranking of education in NTT is the fourth-lowest in Indonesia, and life expectancy is also the sixth lowest compared to other provinces. The poverty rate shows as the third poorest province in Indonesia with a sparse population, reaching $22.01 \%$ of the people, far higher than the national of $10.7 \%$ [Bappenas 2017].

Life expectancy is used to assess health status. Besides, it is one indicator that is taken into account in evaluating the HDI. The description of NTT residents in 2015 has a life expectancy of 65.96, which means that children born in 2015 are expected to live on average until the age of 66. In 2016 the life expectancy rate was 66.04 , which means that children born in 2016 are expected to live on average until the age of 67 years, and in 2017 the life expectancy rate is 66.07. The life expectancy of the population every year is increasing but not too significantly, only around $1-5$ months $^{2}$.

For cases of infant mortality, children under five and toddlers in NTT show fluctuating numbers. The highest number of infant deaths occurred in 2016, as many as 1,689 , the highest number of deaths of children under five were 449 in 2016, and the highest number of infant deaths was 1,174 in 2017. The highest number of infant deaths occurred in Kupang District in 2015 as many as 198. The highest number of child deaths under five years of age occurred in 2015 in South Central Timor District and the highest number of under-five deaths in the South. While maternal deaths cases in the province have decreased from year to year, in 2013, the number of maternal deaths was 176 cases, declining in 2014 by 158 cases, for 2016 and 2017 respectively it was 182 and 163 cases $^{3}$.

From another health dimension, malnutrition is a condition in which a person is declared malnourished, or in other words, his nutritional status is below average standards. Nutrition in question can be in the form of protein, carbohydrates, and calories. In Indonesia, the case of Protein Energy Deficiency is one of the leading nutritional problems that are often found in toddlers [Ariesthi 2018]. The percentage of children under five years of age in the province of NTT declined from 2015 to 2017 but is still the highest in Indonesia. The increase occurred in the percentage of children under five and under five years old wasting and underweight ${ }^{4}$.

\footnotetext{
${ }^{1}$ Kementerian Perencanaan Pembangunan Nasional [Ministry of National Development Planning of the Indonesian Republic] website, https://www.bappenas.go.id/files/5613/5229/8326/bab28_20090202204616_1756_29.pdf [accessed: 26.08.2019].

${ }^{2}$ Badan Pusat Statistik Nusa Tenggara Timur - BPS NTT [East Nusa Tenggara Central Statistics Agency] website, https:// ntt.bps.go.id/pressrelease/2018/05/07/699/indeks-pembangunan-manusia-2017-mencapai-63-73.html and https://ntt.bps. go.id/pressrelease/2017/04/20/635/ipm-nusa-tenggara-timur-tahun-2016.html [accessed: 26.08.2019].

${ }^{3}$ Sistem Informasi Pembangunan Daerah Provinsi Nusa Tenggara Timur - SIPD NTT [East Nusa Tenggara Regional Development Information] in Rencana Pembangunan Jangka Menengah Daerahprovinsi Nusa Tenggara Timur - RPJMD NTT (2018). Nusa Tenggara Timur Province Medium Term Development Plan for period 2018-2023, Kupang.

${ }^{4}$ Kementerian Kesehatan [Minister of the Health of the Indonesian Republic] website, https://pusdatin.kemkes.go.id/resources/download/pusdatin/profil-kesehatan-indonesia/PROFIL_KESEHATAN_2018_1.pdf [accessed: 26.08.2019].
} 
In access to health services in NTT, Community Health Centre (Puskesmas) is the health facility most frequently used by the people of NTT. In general, outpatient care without medical treatment at Puskesmas is the most widely used treatment by the community in NTT. Still, the cost is more expensive than the national average. There is a gap in the number of medical staff when compared to the national scale. In NTT, there are 1.4 doctors per Puskesmas, which is lower than the national average of 1.8 doctors per Puskesmas. For midwives who work at the health centre in NTT are also more economical than the national average. The limited number of general practitioners, specialists, and dentists can reduce the quality of services provided to residents in Puskesmas working area. The province of NTT is also one of the regions with the highest number of malnutrition sufferers in Indonesia [Ramadhini 2015].

\section{CONCLUSIONS}

Puskesmas is a leading health facility that provides primary health services to the community. However, since 2000 , in the era of decentralisation and regional autonomy, the management and supervision of Puskesmas were left to the district/city government. Thus the development of Puskesmas varied and depended on local commitment and capacity.

Fulfilment of the availability of health service facilities and infrastructure in health centres and their networks in border areas is at least equivalent to the health services of neighbouring countries. There is a need to provide incentives to health care workers. Also, competent health workers need to be increased in their competence, such as conducting training towards better quality services. And they also need to meet the availability of transportation, such as motorcycles, four-wheeled vehicles, certain types of health vessels according to the existing regional topography.

\section{Acknowledgements}

This research was conducted, thanks to Simlibtamas research funding in 2019, provided by the Ministry of Research, Technology, and Higher Education Services Region III Jakarta. The researcher also thanks LPPM-UKI and all those who helped.

\section{REFERENCES}

Ariesthi, K.D. (2018). Gizi buruk pada balita di NTT, mengapa sulit diakhiri? Retrieved from https://theconversation.com/gizi-buruk-pada-balita-di-ntt-mengapa-sulitdiakhiri-91841 [accessed: 26.08.2019].

Baker, T.D., Reinke, W.A. (1994). Dasar Epidemiologi untuk Perencanaan Kesehatan. Dalam: Perencanaan Kesehatan Untuk Meningkatkan Efektivitas Manajemen. Gadjah Mada University Press, Yogyakarta.

Bappenas (2017). PrADa Regional Profile and Analysis of the Province of Nusa Tenggara Timur 2017. Deputy for Regional Development Ministry of PP/Bappenas of the Indonesian Republic, Jakarta.

Budiarto, W., Suprapto, A., Ristrini, R. (2007). Studi tentang Rekruitmen, Seleksi dan Alokasi Kegiatan Tenaga Keperawatan di Daerah Terpencil di Jatim dan NTT. Buletin Penelitian Sistem Kesehatan, 10 (2). Retrieved from http://ejournal.litbang.kemkes.go.id/index.php/ hsr/article/view/1777/2584 [accessed: 26.08.2019].

Budiarto, W., Suprapto, A., Sarwanto, Ristrini, Busisuari, M.A. (2005). Pengembangan Model Rekruitmen dan Pendayagunaan Tenaga Keperawatan di Daerah Terpencil. Badan Penelitian dan Pengembangan Kesehatan: Pusat Penelitian dan Pengembangan Sistem dan Kebijakan Kesehatan Abstrak Hasil Penelitian, Surabaya.

Cevik, C., Sozmen, K., Kilic, B. (2017). How Primary Care Reforms Influenced Health Indicators in Manisa District in Turkey: Lessons for General Practitioners. European Journal of General Practice, 24 (1), 74-83, https://doi. org/10.1080/13814788.2017.1410538

Handayani, L., Evie, S., Siswanto (2006). Upaya Revitalisasi Pelayanan Kesehatan Puskesmas dan Jaringannya dalam rangka Peningkatan Kualitas Pelayanan Kesehatan. Badan Penelitian dan Pengembangan Kesehatan: Pusat Penelitian dan Pengembangan Sistem dan Kebijakan Kesehatan. Laporan Akhir Penelitian. Surabaya.

Kennedy, P.S.J., Tobing, S.J.L., Heatubun, A.B., Toruan, R.L. (2018). Strategic Issues of Indonesian Border Area Development based on The Master Plan 2015-2019. [In:] Proceeding International Seminar on Accounting for Society, Faculty of Economy Universitas Pamulang, 21 March 2018, 190-198. Retrieved from: http://openjournal.unpam.ac.id/index.php/Proceedings/article/ view/1830/1527 [accessed: 27.08.2019].

Klimczuk, A., Klimczuk-Kochańska, M. (2015). Technology transfer. [In:] M. Odekon (Ed.), The SAGE encyclopedia of world poverty. 2nd ed. SAGE, Los Angeles, $1529-1531$. 
Li, X., Lu, J., Hu, S., Cheng, K.K., De Maeseneer, J., Meng, Q., Mossialos, E., Xu, D.R., Yip, W., Zhang, H., Krumholz H.M., Jiang, L., Hu, S. (2017). The primary healthcare system in China. The Lancet, 390 (10112), 2584-2594, https://doi.org/10.1016/S0140-6736(17)33109-4

Magnusson, L., Ottosson, J. (2009). The evolution of path dependence. Edward Elgar, Cheltenham/Northampton.

Muldoon, L.K., Hogg, W.E., Levitt, M. (2006). Primary Care (PC) and Primary Health Care (PHC): What is the Difference? Canadian Journal of Public Health, 97 (5), 409-411.

Peraturan Menteri Kesehatan Nomor 43 Tahun 2016 Tentang Standar Pelayanan Minimal Bidang Kesehatan [Regulation No 43/2016 of the Minister of the Health concerning minimum helath service standards].

Peraturan Menteri Kesehatan Republik Indonesia Nomor 75 Tahun 2014 Tentang Pusat Kesehatan Masyarakat [Regulation No 75/2014 of the Minister of the Health Minister on community health centres].

Ramadhini (2015). Kesenjangan Sosial dalam Akses terhadap Pelayanan Kesehatan di Provinsi Nusa Tenggara Timur. Rekomendasi terhadap Kebijakan Peraturan Daerah Provinsi NTT Nomor 1 Tahun 2014 tentang Rencana Pembangunan Jangka Menengah Daerah, FISIP UI, Jakarta.

Rencana Pembangunan Jangka Menengah Daerahprovinsi Nusa Tenggara Timur - RPJMD NTT (2018). Nusa Tenggara Timur Province Medium Term Development Plan for period 2018-2023, Kupang.

Ristrini, Sulistyowati, Siswanto, 2004. Intervensi Pemberdayaan Masyarakat Melalui Penumbuhkembangan Upaya Kesehatan yang Berbasis Masyarakat Miskin di Pedesaan dalam rangka "Making Pregnancy Safer". Badan Penelitian dan Pengembangan Kesehatan: Pusat Penelitian dan Pengembangan Sistem dan Kebijakan Kesehatan. Laporan Akhir Penelitian, Surabaya.

Shanteukie WordPress (2011). Mempertanyakan kembali Nasionalisme Masyarakat di Kalimantan Barat (Perbatasan RI - Malaysia). Retrieved from https://shanteukie.wordpress.com/2011/04/20/mempertanyakankembali-nasionalisme-masyarakat-di-kalimantanbarat-perbatasan-ri-\%E2\%80\%93-malaysia [accessed: 27.08.2019].

Suharmiati, S., Laksono, A.D., Astuti, W.D. (2013). Review Kebijakan tentang Pelayanan Kesehatan Puskesmas di Daerah Terpencil Perbatasan [Policy Review on Health Services in Primary Health Center in the Border and Remote Area]. Buletin Penelitian Sistem Kesehatan, 16 (2), 109-116.

Timyan, Y. (1997). Akses pelayanan: Bukan Sekedar Masalah Jarak. Dalam: Kesehatan Wanita, Sebuah Perspektif Global. Gadjah Mada University Press, Yogjakarta.

Triwahyuni, D. (2010). Masalah Kemiskinan dan Kesenjangan Pendapatan di Indonesia.

World Health Organization - WHO (1978). Declaration of Alma Ata. International Conference on Primary Health Care, Alma-Ata, Kazakhstan, 6-12 September 1978.

World Health Organization - WHO (2008). The World Health Report 2008: Primary Health Care (Now More Than Ever). World Health Organization, Geneva.

World Health Organization - WHO (2012). Good Practices in Delivery of Primary Health Care in Urban Settings. UNRWA - WHO study. World Health Organization, Geneva.

\section{PROBLEMY POLITYKI ZDROWOTNEJ W REGIONIE GRANICZNYM INDONEZJ}

\section{STRESZCZENIE}

Artykuł ma na celu zbadanie problemów polityki zdrowotnej na obszarach przygranicznych Indonezji. Badanie w sposób szczególny koncentruje się na problemach zdrowotnych w prowincji Nusa Tenggara Timur. Zastosowano metody opisowo-ilościowe. W wyniku analizy stwierdzono, że konieczne jest dalsze intensywe rozwijanie infrastruktury ochrony zdrowia na obszarach przygranicznych. Niezbędne są także uspołecznienie oraz usprawnienie usług ubezpieczenia zdrowotnego świadczonych przez rząd, a także poprawa zasobów ludzkich w sektorze zdrowia.

Słowa kluczowe: polityka zdrowotna, problemy zdrowotne, obszar przygraniczny, Nusa Tenggara Timur 